\author{
Marian Podstawka \\ Szkoła Gtówna Gospodarstwa Wiejskiego w Warszawie \\ Agnieszka Deresz
}

\title{
Zróżnicowanie obciążeń fiskalnych dochodów osób fizycznych w Polsce
}

\section{DIFFERENTIATION OF TAX BURDEN ON INDIVIDUAL TAXPAYERS IN POLEN}

\begin{abstract}
Opodatkowanie to złożone zjawisko społeczne, gospodarcze, a także politycznoustrojowe i prawne. Podatki byly i sq przede wszystkim narzędziem stużacym do gromadzenia przez państwo środków niezbędnych do realizacji jego zadań. Ponadto podatki sq zwiazane z regulowaniem procesów gospodarczych i społecznych, co oznacza, że podatki petnia funkcje: redystrybucyjna, stymulacyjnq $i$ alokacyjnq. Znaczenie gospodarczo społeczne podatków polega na tym, że skutkiem ich nakładania jest zmiana sytuacji dochodowej i majatkowej podatników, co wptywa na podejmowane ich decyzje: gospodarcze, konsumpcyjne, o oszczędzaniu, itp. Zmiany systemu podatkowego $w$ latach 2008-2015, miaty wptyw na ksztaltowanie sie nominalnych $i$ efektywnych stawek podatkowych. Wysokości obciqżen podatkowych i innych obciażen fiskalnych naktadanych na poszczególne grupy podatników spowodowaty zmiany $w$ obciqżeniu ich dochodów. Celem artykułu jest ocena rozkładu obciqżeń fiskalnych w Polsce w latach 2008-2015. $W$ opracowaniu, na podstawie przedmiotowej oceny, podjęto próbę weryfikacji hipotezy, że obciażenia fiskalne naktadane na osoby fizyczne prowadzqce pozarolniczq dziatalność gospodarcza sq niższe $w$ porównaniu $z$ opodatkowaniem wynagrodzeń $z$ innych źródel przychodów.
\end{abstract}

Słowa kluczowe: pozarolnicza działalność gospodarcza, wynagrodzenia $\mathrm{z}$ innych źródeł przychodów, składki na ubezpieczenia społeczne, składka na ubezpieczenie zdrowotne, podatek należny

\section{Wstęp}

System podatkowy podlega nieustannie ewolucji. Zmienne w czasie są też funkcje podatków. Początkowo podatki były podporządkowane realizacji jedynie funkcji fiskalnej. Doktryna liberalna traktowała je jako narzędzie neutralne, nie powodujące zmian realnych wielkości gospodarczych. Niemiecki ekonomista Adolph Wagner pierwszy położył nacisk na to, że opodatkowanie powinno służyć zmniejszaniu nierówności dochodów. Mimo, że postulat ten początkowo budził wiele kontrowersji, z czasem zaczął być coraz częściej stosowany w praktyce. W wieku XX głównie pod wpływem teorii Johna Maynarda Keynesa, potrzeba wykorzystywania podatków w celach pozafiskalnych stała się sprawą bezsporną. Obecnie oprócz tradycyjnej roli fiskalnej, podatki spełniają różnorodne funkcje o charakterze społecznym i gospodarczym. Podatek dochodowy od osób fizycznych ma zapewnić państwu dochody, 
które umożliwiają realizację jego funkcji, a jednocześnie ma wpływać na gospodarcze i społeczne zachowania podatników.

Funkcja fiskalna podatku dochodowego od osób fizycznych wynika $\mathrm{z}$ konieczności zagwarantowania budżetowi państwa i budżetom lokalnym odpowiednich dochodów niezbędnych na realizację zaplanowanych zadań. Polega ona na przejmowaniu od podatników środków pieniężnych na rzecz państwa bądź innego związku publicznoprawnego. Wynika to z samej istoty podatków, które są zasadniczymi źródłami dochodów budżetowych, stąd też to z samej istoty podatków funkcja fiskalna przedstawia się jako podstawowa. Definicja podatku zawarta w ustawie Ordynacja podatkowa $^{1}$ oznacza, że podstawowym celem podatku jest konieczność zapewnienia środków finansowych na pokrycie wydatków publicznych.

Do pozafiskalnych funkcji podatków, należą przede wszystkim funkcja redystrybucyjna, stymulacyjna i alokacyjna. Funkcja redystrybucyjna wynika z konieczności kształtowania przez państwo majątku i dochodów będących w posiadaniu podatników. Właściwie jest przejawem korygowania dochodów uznanych za wysokie u jednych podatników i za niskie u drugich podatników. Państwo próbuje „poprawić” proporcje podziału dochodu narodowego pomiędzy różne grupy społeczne, dokonanego przez rynek. Funkcja stabilizacyjna polega na wykorzystaniu podatków w celu oddziaływania na koniunkturę gospodarczą. Podatki stają się tu elementem polityki dostosowawczej państwa, której celem jest zapewnienie zrównoważonego wzrostu gospodarczego, pełnego zatrudnienia oraz równowagi bilansu płatniczego. Funkcja alokacyjna podatków związana jest z występowaniem efektów zewnętrznych. Państwo próbuje ,poprawić” alokację zasobów dokonaną przez rynek. W podatku dochodowym od osób fizycznych pozafiskalne funkcje podatków znalazły odzwierciedlenie w progresji podatkowej, kwocie wolnej od podatków, ulgach, preferencjach oraz zwolnieniach podatkowych, jak również w zróżnicowanych stawkach podatku od towarów i usług i w akcyzie.

Za pomocą polityki społecznej podejmowane są decyzje o tym, co kto otrzymuje w społeczeństwie. Za sprawą polityki podatkowej decyzje te określają, kto płaci podatki i w jakiej wysokości, kto może korzystać z ulg i preferencji podatkowych. Powstaje zatem pytanie, czy dokonany podział dóbr i obciążeń podatkowych jest sprawiedliwy. Zharmonizowany system podatkowy zmniejsza stopień wyłudzania podatków, czego efektem jest bardziej skuteczna możliwość zmniejszania deficytu budżetowego, dostateczne spożytkowanie korzyści płynących ze wzrostu gospodarczego, jak również wzrost środków finansowych na realizację polityki społecznej. Urynkowienie polskiej gospodarki, obok wielu zjawisk pozytywnych spowodowało także zjawiska negatywne, jak np. bezrobocie, zubożenie niektórych grup społecznych, wzrost kosztów utrzymania gospodarstw domowych.

Celem opracowania jest przedstawienie w latach 2008-2015 obciążeń fiskalnych dochodów osób fizycznych prowadzących pozarolniczą działalność gospodarczą w porównaniu $\mathrm{z}$ obciążeniami fiskalnymi dochodów osób fizycznych uzyskujących przychody z pozostałych źródeł z wykorzystaniem danych zawartych w Informacjach

\footnotetext{
${ }^{1}$ Zgodnie z art. 6 ustawy z 29 sierpnia 1997r. Ordynacja podatkowa (tekst jednolity Dz.U. z 2017r. poz. 201 ze zm.) podatkiem jest publicznoprawne, nieodpłatne, przymusowe oraz bezzwrotne świadczenie pieniężne na rzecz Skarbu Państwa, województwa, powiatu lub gminy, wynikające z ustawy podatkowej.
} 
Ministerstwa Finansów dotyczących rozliczenia podatku dochodowego od osób fizycznych oraz ryczałtu od przychodów ewidencjonowanych. Badania dotyczą okresu gdy: w 2008 roku obowiązywała progresywna skala podatkowa z trzema stawkami podatkowymi w wysokości: 19\%, 30\% i 40\%, w 2009 roku wprowadzono dwustawkową skalę podatkową: $18 \%$ i 32\%, oraz okres 2010-2015 w którym progi podatkowe pozostały na niezmienionej wysokości.

Hipoteza: Obciążenia fiskalne nakładane na osoby fizyczne prowadzące pozarolniczą działalność gospodarczą są niższe w porównaniu $\mathrm{z}$ osobami osiagającymi dochody $\mathrm{z}$ innych źródeł.

\section{Preferencje podatkowe dla przedsiębiorców}

W polskiej opinii publicznej dominuje przekonanie, że przedsiębiorcy są zbyt mocno obciążeni podatkami, co ogranicza ich możliwości rozwojowe oraz osłabia pozycję konkurencyjną na rynkach światowych. Osoby fizyczne prowadzące pozarolniczą działalność gospodarczą, w odróżnieniu od osób fizycznych uzyskujących przychody z innych źródeł, np. wynagrodzenia ze stosunku pracy, umowy zlecenia czy praw autorskich posiadają legalne sposoby na płacenie niższych podatków.

Po pierwsze: osoby fizyczne prowadzące pozarolniczą działalność gospodarczą, czy też rozpoczynające jej prowadzenie mają prawo do wyboru form opodatkowania podatkiem dochodowym spośród czterech możliwych:

- Opodatkowania na zasadach ogólnych:

- według progresywnej skali podatkowej - z możliwością korzystania z ulg podatkowych i preferencyjnych sposobów opodatkowania,

- według stawki liniowej 19\% - niezależnie od wysokości dochodów, ale bez możliwości korzystania z ulg podatkowych i preferencyjnych sposobów opodatkowania,

Opodatkowania w formach zryczałtowanych:

- według ryczałtu ewidencjonowanego - ze stawkami 3\%, 5,5\%, 8,5\%, 10\%, $17 \%$ i $20 \%$ w zależności od rodzaju prowadzonej działalności gospodarczej,

- $\quad$ według karty podatkowej - ze stałą kwotą podatku niezależnie od wartości faktycznie uzyskiwanych przychodów.

W zależności od rodzaju prowadzonej działalności gospodarczej, jej rozmiaru oraz poziomu ponoszonych kosztów uzyskania przychodu, przedsiębiorca może wybrać formę opodatkowania najbardziej optymalną. Następstwem wyboru optymalnej formy opodatkowania są znaczne oszczędności finansowe, co niewątpliwie zwiększa opłacalność prowadzenia pozarolniczej działalności gospodarczej.

Po drugie: osoby fizyczne prowadzące pozarolniczą działalność gospodarczą mają prawo do płacenia zaliczki na podatek dochodowy w trakcie roku w formie uproszczonej, co pozwala na przesunięcie największego obciążenia podatkowego na koniec kwietnia następnego roku. Pieniądze, które pozostają w dyspozycji przedsiębiorcy mogą zostać wykorzystane na różnego rodzaju inwestycje oraz zwiększenie kapitału obrotowego przedsiębiorstwa.

Po trzecie: Zarówno w przypadku podatku dochodowego, jak i podatku od towarów i usług przedsiębiorca ma możliwość płacenia w okresach miesięcznych i 
kwartalnych. Rozliczanie kwartalne powoduje, że przedsiębiorca ma do dyspozycji gotówkę, którą przy rozliczaniu miesięcznym musiałby wpłacić na konto organu podatkowego, a możliwości jej wykorzystania jest przecież wiele. Ponadto, wybierając za okresy rozliczeniowe kwartały zamiast miesięcy, przedsiębiorca łatwiej może utrzymać płynność finansową swojej firmy. Jest to również doskonałe rozwiązanie dla firm, w których koszty i przychody rozkładają się nierównomiernie w poszczególnych miesiącach. Dzięki opłacaniu podatków co kwartał przedsiębiorca ma więcej czasu na zgromadzenie faktur kosztowych, dzięki czemu łatwiej mu utrzymać równowagę finansowa.

Po czwarte: osoby fizyczne rozpoczynające pozarolniczą działalność gospodarczą mają prawo do skorzystania $\mathrm{z}$ ulg dla nowo powstałych przedsiębiorstw. Pierwsza z nich to możliwość skorzystania $\mathrm{z}$ jednorazowej amortyzacji $\mathrm{w}$ ramach pomocy de minimis, druga to opłacanie składek ubezpieczeniowych na preferencyjnych warunkach. Dzięki tym możliwościom zwiększa się płynność finansowa przedsiębiorstwa. Jednorazowa amortyzacja to również zmniejszenie podstawy opodatkowania, a przez to także niższy podatek dochodowy. Płacenie preferencyjnych składek ZUS to również duża oszczędność. Dzięki tym rozwiązaniom do dyspozycji przedsiębiorcy pozostają dodatkowe środki, które może on wykorzystać na wiele różnych sposobów.

Po piąte: Przy opłacaniu podatku dochodowego na zasadach ogólnych, wysokość zaliczek obliczana jest jako procent podstawy opodatkowania. Im jest ona niższa, tym niższy jest podatek. Podstawa opodatkowania obliczana jest natomiast między innymi jako różnica między osiagniętym przychodem a poniesionymi kosztami jego uzyskania. Mądre planowanie wydatków firmowych oraz wiedza na temat tego, co i jak można zaewidencjonować jako koszt uzyskania przychodu, może poprzez obniżenie podstawy opodatkowania, znacząco wpłynąć na wysokość płaconych podatków.

\section{Obciążenia podatkowe przedsiębiorców oraz podatników uzyskujących wynagrodzenia z innych źródel przychodów}

Porównanie obciążeń podatkowych podatników o dochodach powyżej 85.528, 00 zł, tj. z III przedziału progresywnej skali podatkowej obowiązującej w 2008 roku i II przedziału progresywnej skali podatkowej obowiązującej w latach 2009-2015, z przedsiębiorcami opodatkowanymi na zasadach ogólnych według stawki liniowej 19\% i według ryczałtu ewidencjonowanego przedstawia tabela 1 .

Tabela 1. Rozkład obciążeń podatkowych w latach 2008-2015.

\begin{tabular}{|c|c|c|c|c|}
\hline & & $\begin{array}{l}\text { III przedzial } \\
\text { podatkowy }\end{array}$ & $\begin{array}{c}\text { Podatek liniowy } \\
19 \%\end{array}$ & $\begin{array}{c}\text { Ryczalt } \\
\text { ewidencjonowany }\end{array}$ \\
\hline \multicolumn{5}{|c|}{2008 rok } \\
\hline \multicolumn{2}{|c|}{ Liczba podatników } & 342.230 & 463.115 & 713.585 \\
\hline \multicolumn{2}{|c|}{$\begin{array}{l}\text { Przeciętny dochód } \\
\text { (w zł) }\end{array}$} & $155.617,84$ & $170.354,83$ & $51.226,00$ \\
\hline Lączne & Przeciętne & $52.343,58$ & $34.283,59$ & $4.428,75$ \\
\hline
\end{tabular}




\begin{tabular}{|c|c|c|c|c|}
\hline \multirow{2}{*}{$\begin{array}{l}\text { obciążenie } \\
\text { dochodu * }\end{array}$} & (w zl) & & & \\
\hline & $(w \%)$ & 33,63 & 20,13 & 8,65 \\
\hline \multicolumn{5}{|c|}{2009 rok } \\
\hline \multicolumn{2}{|l|}{ Liczba podatników } & 387.295 & 391.784 & 732.760 \\
\hline \multicolumn{2}{|l|}{$\begin{array}{l}\text { Przeciętny dochód } \\
\text { (w zł) }\end{array}$} & $162.951,40$ & $180.428,00$ & $44.976,38$ \\
\hline \multirow[t]{2}{*}{$\begin{array}{l}\text { Lączne obciążenie } \\
\text { dochodu }\end{array}$} & $\begin{array}{c}\text { przeciętne (w } \\
\text { zl) }\end{array}$ & $45.039,29$ & $36.358,84$ & $4.210,00$ \\
\hline & $(w \%)$ & 27,64 & 20,16 & 9,36 \\
\hline \multicolumn{5}{|c|}{2010 rok } \\
\hline \multicolumn{2}{|l|}{ Liczba podatników } & 463.567 & 395.039 & 791.089 \\
\hline \multicolumn{2}{|l|}{$\begin{array}{l}\text { Przeciętny dochód } \\
\text { (w zl) }\end{array}$} & $150.337,86$ & $188.986,66$ & $45.435,12$ \\
\hline \multirow[t]{2}{*}{$\begin{array}{l}\text { Lączne obciążenie } \\
\text { dochodu }\end{array}$} & $\begin{array}{c}\text { przeciętne (w } \\
\text { zl) }\end{array}$ & 41.138,37 & $37.884,19$ & $4.041,85$ \\
\hline & $(w \%)$ & 27,36 & 20,05 & 8,89 \\
\hline \multicolumn{5}{|c|}{2011 rok } \\
\hline \multicolumn{2}{|l|}{ Liczba podatników } & 521.600 & 410.813 & 835.514 \\
\hline \multicolumn{2}{|l|}{$\begin{array}{l}\text { Przeciętny dochód } \\
\text { (w zł) }\end{array}$} & $149.633,55$ & $199.854,19$ & $47.554,64$ \\
\hline \multirow[t]{2}{*}{$\begin{array}{l}\text { Lączne obciążenie } \\
\text { dochodu }\end{array}$} & $\begin{array}{c}\text { przeciętne (w } \\
\text { zl) }\end{array}$ & 41.192,74 & $40.069,70$ & $4.239,40$ \\
\hline & $(\mathrm{w} \%)$ & 27,53 & 20,05 & 8,92 \\
\hline \multicolumn{5}{|c|}{2012 rok } \\
\hline \multicolumn{2}{|l|}{ Liczba podatników } & 554.382 & 429.096 & 877.371 \\
\hline \multicolumn{2}{|l|}{$\begin{array}{l}\text { Przeciętny dochód } \\
\text { (w zł) }\end{array}$} & $160.178,11$ & $187.152,60$ & $45.204,68$ \\
\hline \multirow[t]{2}{*}{$\begin{array}{l}\text { Lączne obciążenie } \\
\text { dochodu }\end{array}$} & $\begin{array}{c}\text { przeciętne (w } \\
\text { zl) }\end{array}$ & $44.413,17$ & $37.938,78$ & $4.193,77$ \\
\hline & $(\mathrm{w} \%)$ & 27,73 & 20,28 & 9,27 \\
\hline \multicolumn{5}{|c|}{2013 rok } \\
\hline \multicolumn{2}{|l|}{ Liczba podatników } & 601.621 & 446.485 & 921.838 \\
\hline \multicolumn{2}{|l|}{$\begin{array}{l}\text { Przeciętny dochód } \\
\text { (w zł) }\end{array}$} & $149.842,82$ & $193.643,34$ & $43.052,38$ \\
\hline \multirow[t]{2}{*}{$\begin{array}{l}\text { Lączne obciążenie } \\
\text { dochodu }\end{array}$} & $\begin{array}{c}\text { przeciętne (w } \\
\text { zl) }\end{array}$ & $41.796,88$ & $39.326,14$ & $4.067,87$ \\
\hline & $(w \%)$ & 14,59 & 20,31 & 9,45 \\
\hline
\end{tabular}




\begin{tabular}{|c|c|c|c|c|}
\hline \multicolumn{5}{|c|}{2014 rok } \\
\hline \multicolumn{2}{|l|}{ Liczba podatników } & 657.764 & 473.954 & 960.847 \\
\hline \multicolumn{2}{|l|}{$\begin{array}{l}\text { Przeciętny dochód } \\
\text { (w zt) }\end{array}$} & $150.401,32$ & $205.335,30$ & $44.724,14$ \\
\hline \multirow[t]{2}{*}{$\begin{array}{l}\text { Lączne obciążenie } \\
\text { dochodu }\end{array}$} & $\begin{array}{c}\text { przeciętne (w } \\
\text { zl) }\end{array}$ & $41.751,38$ & $41.531,54$ & $4.182,92$ \\
\hline & $(w \%)$ & 27,76 & 20,23 & 9,36 \\
\hline \multicolumn{5}{|c|}{2015 rok } \\
\hline \multicolumn{2}{|l|}{ Liczba podatników } & 710.471 & 502.648 & 1.003 .987 \\
\hline \multicolumn{2}{|l|}{$\begin{array}{l}\text { Przeciętny dochód } \\
\text { (w zł) }\end{array}$} & $150.771,99$ & $220.024,00$ & $45.789,19$ \\
\hline \multirow[t]{2}{*}{$\begin{array}{l}\text { Lączne obciążenie } \\
\text { dochodu }\end{array}$} & $\begin{array}{c}\text { przeciętne (w } \\
\text { zl) }\end{array}$ & $41.896,61$ & $44.480,36$ & $4.315,57$ \\
\hline & $(\mathrm{w} \%)$ & 27,80 & 20,22 & $\mathbf{9 , 4 4}$ \\
\hline
\end{tabular}

* obciążenie dochodu podatnika $\mathrm{z}$ tytułu składek na ubezpieczenia społeczne, ubezpieczenie zdrowotne oraz podatku należnego

Źródło: Opracowanie własne na podstawie Informacji Ministerstwa Finansów dotyczących rozliczenia podatku dochodowego od osób fizycznych za lata 2008-2015 oraz Informacji dotyczących ryczałtu od przychodów ewidencjonowanych za lata 2008-2015, Ministerstwo Finansów, Departament Podatków Dochodowych

Przedstawione w powyższej tabeli porównanie obciążeń dochodów podatników opodatkowanych według progresywnej skali podatkowej oraz przedsiębiorców wybierających opodatkowanie dochodów podatkiem liniowym w wysokości 19\% lub opodatkowanie przychodów ryczałtem ewidencjonowanym wyraźnie pokazuje uprzywilejowaną pozycję przedsiębiorców na tle dochodów uzyskiwanych $\mathrm{z}$ innych źródeł przychodów, np. z wynagrodzenia ze stosunku pracy, umowy zlecenie czy praw autorskich. $Z$ analizy danych $z$ tabeli 1 wynika, że najwyższe łączne obciążenie dochodu dotyczy grupy podatników opodatkowanych według progresywnej skali podatkowej. $\mathrm{Na}$ drugim miejscu pod tym względem znaleźli się przedsiębiorcy opodatkowani podatkiem liniowych w wysokości 19\%, natomiast najniższe łączne obciążenie dochodu dotyczy przedsiębiorców opodatkowanych ryczałtem ewidencjonowany.

W 2008 roku łączne fiskalne obciążenie dochodu podatników opodatkowanych według progresywnej skali podatkowej wyniosło 52.343,58 zł, co stanowi 33,63\% przeciętnego dochodu tej grupy podatników stanowiącego kwotę 155.617,84 zł, natomiast przedsiębiorców opodatkowanych podatkiem liniowym w wysokości 19\% $34.283,59$ zł, co stanowi 20,13\% przeciętnego ich dochodu w wysokości 170.354,83 zł, a przedsiębiorców opodatkowanych ryczałtem ewidencjonowanym tylko 4.428,75 zł, co stanowi 8,65\% przeciętnego przychody - 51.226,00 zł. Obniżenie łącznego fiskalnego obciążenia dochodu zarówno podatników opodatkowanych według progresywnej skali podatkowej, jak i przedsiębiorców opodatkowanych podatkiem liniowym oraz ryczałtem ewidencjonowanym nastąpiło w 2009 roku, kształtując się odpowiednio na poziomie $45.039,29$ zł, 36.358,84 zł i 4.210,00 zł, co stanowi odpowiednio 27,64\% przeciętnego 
dochodu w wysokości 162.951,40 zł, 20,16\% przeciętnego dochodu w wysokości $180.428,00$ zł i 9,36\% przeciętnego przychodu w wysokości 44.976,38 zł. W 2010 roku łączne fiskalne obciążenie dochodu podatników opodatkowanych według progresywnej skali podatkowej wyniosło 41.138,37 zł, w 2011 roku 41.192,74 zł, w 2012 roku 44.413,17 zł, w 2013 roku 41.796,88 zł, w 2014 roku 41.751,38 zł i w 2015 roku 41.896,61 zł, przedsiębiorców opodatkowanych podatkiem liniowym kształtowało się na niższym poziomie wynosząc w 2010 roku 37.884,19 zł, w 2011 roku 40.069,70 zł, w 2012 roku 37.938,78 zł, w 2013 roku 39.326,14 zł, w 2014 roku 41.531,54 zł i w 2015 roku 44.480,36 zl, natomiast przedsiębiorców opodatkowanych ryczałtem ewidencjonowanym na poziomie: w 2010 roku 4.041,85 zl, w 2011 roku 4.239,40 zł, w 2012 roku 4.193,77 zł, w 2013 roku 4.067,87 zl, w 2014 roku 4.182,92 zł i w 2015 roku 4.315,57 zł. Udział łącznego fiskalnego obciążenia dochodu w przeciętnym dochodzie podatników opodatkowanych według progresywnej skali podatkowej w latach 20102015 kształtował się na zbliżonym poziomie wynosząc powyżej $27 \%$. Na znacznie niższy poziomie kształtował się udział łącznego fiskalnego obciążenia dochodu w przeciętnym dochodzie przedsiębiorców opodatkowanych podatkiem liniowym. W latach 2010-2015 wyniósł on niewiele powyżej 20\%. W najniższym stopniu obciążone były przychody przedsiębiorców opodatkowanych ryczałtem ewidencjonowanym, bo w latach 2010-2015 na poziomie około 9\%.

W tabeli 2 zaprezentowano różnice między łącznym obciążeniem fiskalnym dochodu podatników opodatkowanych według progresywnej skali podatkowej a przedsiębiorców opodatkowanych według stawki liniowej w wysokości 19\% i ryczałtu ewidencjonowanego. Przedmiotowe różnice przedstawiono w ujęciu kwotowym, jak i procentowym.

Tabela 2. Różnice w łącznych obciążeniach fiskalnych dochodu w ujęciu kwotowych i procentowym.

\begin{tabular}{|c|c|c|}
\hline & $\begin{array}{c}\text { Przeciętne lączne } \\
\text { obciążenie fiskalne } \\
\text { dochodu (w zl) }\end{array}$ & $\begin{array}{c}\text { Udzial lącznego } \\
\text { obciążenia } \\
\text { fiskalnego w } \\
\text { przeciętnym } \\
\text { dochodzie (w } \\
\% \text { ) }\end{array}$ \\
\hline \multicolumn{3}{|c|}{2008 rok } \\
\hline III przedział & $52.343,58$ & 33,63 \\
\hline Podatek liniowy $19 \%$ & $34.283,59$ & 20,13 \\
\hline Ryczałt ewidencjonowany & $4.428,75$ & 8,65 \\
\hline $\begin{array}{l}\text { Różnica między łącznym obciążeniem fiskalnym } \\
\text { dochodu podatników opodatkowanych według } \\
\text { progresywnej skali podatkowej a przedsiębiorców } \\
\text { opodatkowanych podatkiem liniowym }\end{array}$ & $18.059,99$ & 13,50 \\
\hline $\begin{array}{l}\text { Różnica między łącznym obciążeniem fiskalnym } \\
\text { dochodu podatników opodatkowanych według } \\
\text { progresywnej skali podatkowej a przedsiębiorców } \\
\text { opodatkowanych ryczałtem ewidencjonowanym }\end{array}$ & $47.914,83$ & 24,98 \\
\hline
\end{tabular}




\begin{tabular}{|c|c|c|}
\hline \multicolumn{3}{|l|}{2009 rok } \\
\hline II przedział & $45.039,29$ & 27,64 \\
\hline Podatek liniowy $19 \%$ & $36.358,84$ & 20,16 \\
\hline Ryczałt ewidencjonowany & $4.210,00$ & 9,36 \\
\hline $\begin{array}{l}\text { Różnica między łącznym obciążeniem fiskalnym dochodu } \\
\text { podatników opodatkowanych według progresywnej skali } \\
\text { podatkowej a przedsiębiorców opodatkowanych podatkiem } \\
\text { liniowym }\end{array}$ & $8.680,45$ & 7,48 \\
\hline $\begin{array}{l}\text { Różnica między łącznym obciążeniem fiskalnym } \\
\text { dochodu podatników opodatkowanych według } \\
\text { progresywnej skali podatkowej a przedsiębiorców } \\
\text { opodatkowanych ryczałtem ewidencjonowanym }\end{array}$ & $40.829,29$ & 18,28 \\
\hline \multicolumn{3}{|l|}{$\begin{array}{ll}2010 \text { rok } \\
\end{array}$} \\
\hline II przedział & $41.138,37$ & 27,36 \\
\hline Podatek liniowy $19 \%$ & $37.884,19$ & 20,05 \\
\hline Ryczałt ewidencjonowany & $4.041,85$ & 8,89 \\
\hline $\begin{array}{l}\text { Różnica między łącznym obciążeniem fiskalnym } \\
\text { dochodu podatników opodatkowanych według } \\
\text { progresywnej skali podatkowej a przedsiębiorców } \\
\text { opodatkowanych podatkiem liniowym }\end{array}$ & $3.254,18$ & 7,31 \\
\hline $\begin{array}{l}\text { Różnica między łącznym obciążeniem fiskalnym } \\
\text { dochodu podatników opodatkowanych według } \\
\text { progresywnej skali podatkowej a przedsiębiorców } \\
\text { opodatkowanych ryczałtem ewidencjonowanym }\end{array}$ & $37.096,52$ & 18,47 \\
\hline \multicolumn{3}{|l|}{2011 rok } \\
\hline II przedział & $41.192,74$ & 27,53 \\
\hline Podatek liniowy $19 \%$ & $40.069,70$ & 20,05 \\
\hline Ryczałt ewidencjonowany & $4.239,40$ & 8,92 \\
\hline $\begin{array}{l}\text { Różnica między łącznym obciążeniem fiskalnym } \\
\text { dochodu podatników opodatkowanych według } \\
\text { progresywnej skali podatkowej a przedsiębiorców } \\
\text { opodatkowanych podatkiem liniowym }\end{array}$ & $36.953,34$ & 7,48 \\
\hline $\begin{array}{l}\text { Różnica między łącznym obciążeniem fiskalnym } \\
\text { dochodu podatników opodatkowanych według } \\
\text { progresywnej skali podatkowej a przedsiębiorców } \\
\text { opodatkowanych ryczałtem ewidencjonowanym }\end{array}$ & $36.953,34$ & 18,61 \\
\hline \multicolumn{3}{|l|}{2012 rok } \\
\hline II przedział & $44.413,17$ & 27,73 \\
\hline Podatek liniowy $19 \%$ & $37.938,78$ & 20,28 \\
\hline Ryczałt ewidencjonowany & $4.193,77$ & 9,27 \\
\hline $\begin{array}{l}\text { Różnica między łącznym obciążeniem fiskalnym } \\
\text { dochodu podatników opodatkowanych według } \\
\text { progresywnej skali podatkowej a przedsiębiorców }\end{array}$ & $6.474,39$ & 7,45 \\
\hline
\end{tabular}




\begin{tabular}{|c|c|c|}
\hline opodatkowanych podatkiem liniowym & & \\
\hline $\begin{array}{l}\text { Różnica między łącznym obciążeniem fiskalnym } \\
\text { dochodu podatników opodatkowanych według } \\
\text { progresywnej skali podatkowej a przedsiębiorców } \\
\text { opodatkowanych ryczałtem ewidencjonowanym }\end{array}$ & $40.219,40$ & 18,46 \\
\hline \multicolumn{3}{|l|}{2013 rok } \\
\hline II przedział & $41.796,88$ & 27,89 \\
\hline Podatek liniowy $19 \%$ & $39.326,14$ & 20,31 \\
\hline Ryczałt ewidencjonowany & $4.067,87$ & 9,45 \\
\hline $\begin{array}{l}\text { Różnica między łącznym obciążeniem fiskalnym } \\
\text { dochodu podatników opodatkowanych według } \\
\text { progresywnej skali podatkowej a przedsiębiorców } \\
\text { opodatkowanych podatkiem liniowym }\end{array}$ & $2.470,74$ & $\mathbf{7 , 5 8}$ \\
\hline $\begin{array}{l}\text { Różnica między łącznym obciążeniem fiskalnym } \\
\text { dochodu podatników opodatkowanych według } \\
\text { progresywnej skali podatkowej a przedsiębiorców } \\
\text { opodatkowanych ryczałtem ewidencjonowanym }\end{array}$ & $37.729,01$ & 18,44 \\
\hline \multicolumn{3}{|l|}{2014 rok } \\
\hline II przedział & $41.751,38$ & 27,76 \\
\hline Podatek liniowy $19 \%$ & $41.531,54$ & 20,23 \\
\hline Ryczałt ewidencjonowany & $4.182,92$ & 9,36 \\
\hline $\begin{array}{l}\text { Różnica między łącznym obciążeniem fiskalnym } \\
\text { dochodu podatników opodatkowanych według } \\
\text { progresywnej skali podatkowej a przedsiębiorców } \\
\text { opodatkowanych podatkiem liniowym }\end{array}$ & 219,84 & 7,53 \\
\hline $\begin{array}{l}\text { Różnica między łącznym obciążeniem fiskalnym } \\
\text { dochodu podatników opodatkowanych według } \\
\text { progresywnej skali podatkowej a przedsiębiorców } \\
\text { opodatkowanych ryczałtem ewidencjonowanym }\end{array}$ & $37.568,46$ & 18,40 \\
\hline \multicolumn{3}{|l|}{2015 rok } \\
\hline II przedział & $41.896,61$ & 27,80 \\
\hline Podatek liniowy $19 \%$ & $44.480,36$ & 20,22 \\
\hline Ryczałt ewidencjonowany & $4.315,57$ & 9,44 \\
\hline $\begin{array}{l}\text { Różnica między łącznym obciążeniem fiskalnym } \\
\text { dochodu podatników opodatkowanych według } \\
\text { progresywnej skali podatkowej a przedsiębiorców } \\
\text { opodatkowanych podatkiem liniowym }\end{array}$ & - & 7,58 \\
\hline $\begin{array}{l}\text { Różnica między łącznym obciążeniem fiskalnym } \\
\text { dochodu podatników opodatkowanych według } \\
\text { progresywnej skali podatkowej a przedsiębiorców } \\
\text { opodatkowanych ryczałtem ewidencjonowanym }\end{array}$ & $37.581,04$ & 18,36 \\
\hline
\end{tabular}

Źródło: Opracowanie własne na podstawie danych z tabeli 1 
Z analizy danych zawartych w tabeli 1 i tabeli 2 wynika, że w latach 2008-2009 przy zbliżonych przeciętnych dochodach podatników opodatkowanych według progresywnej skali podatkowej według najwyższej stawki podatkowej wynoszącej w 2008 roku - 40\% a w latach 2009-2015 - 32\% i przedsiębiorców opodatkowanych według stawki liniowej w wysokości 19\% różnice zarówno w kwocie łącznego obciążenia dochodów, jak i w ujęciu procentowym są duże. Należy jednak zauważyć, że w 2008 roku różnica w kwocie obciążenia dochodu była ponad dwukrotnie wyższa niż w 2009 roku (w 2008 roku stanowiła kwotę 18.059,99 zł, w 2009 roku - kwotę 8.680,45 zł), natomiast różnica w ujęciu procentowym była blisko dwukrotnie wyższa (w 2008 roku wynosiła 13,50\%, w 2009 roku - 7,48\%). Wskazuje to na wzmocnienie w 2009 roku dystrybucyjnego znaczenia podatku dochodowego w stosunku do osób fizycznych prowadzących pozarolniczą działalność gospodarczą. Oznacza to, że wprowadzenie dwustawkowej skali podatkowej miało wpływ na zmniejszenie zakresu nierówności dochodów tych podatników. W kolejnych latach 2010-2015, kiedy znacznie wzrosły różnice pomiędzy przeciętnymi dochodami podatników opodatkowanych stawką 32\% i przedsiębiorców opodatkowanych według stawki liniowej 19\%, zmniejszyły się różnice w kwotach obciążenia dochodu tych podmiotów, natomiast różnice w ujęciu procentowym kształtowały się w granicach od 7,31\% do 7,59\%. Oznacza to, że w latach 2009-2015 podatek dochodowy w porównywalnym stopniu pełnił funkcje redystrybycyjną dochodów dla osób fizycznych prowadzących pozarolniczą działalność gospodarczą i realizujących dochody z innych źródeł. Należy również zauważyć, że w największym stopniu na przedmiotowe różnice w każdym $\mathrm{z}$ analizowanych lat wpływały dużo niższe stawki składek na ubezpieczenia społeczne i na ubezpieczenie zdrowotne płacone przez przedsiębiorców.

Analizując obciążenia przychodów przedsiębiorców opodatkowanych według ryczałtu ewidencjonowanego, bezdyskusyjnym jest że były one znacznie niższe niż przedsiębiorców opodatkowanych na zasadach ogólnych, i kształtowały się na poziomie od 8,65\% w 2008 roku do 9,45\% w 2013 roku (w 2015 roku wnosiły 9,44\%).

\section{Podsumowanie}

Przeprowadzone w opracowaniu rozważania pozwalają zweryfikować hipotezę, że obciążenie dochodów jakie jest nakładane na osoby fizyczne prowadzące pozarolniczą działalność gospodarczą są niższe w porównaniu $\mathrm{z}$ obciążeniami fiskalnymi wynagrodzeń z innych źródeł. Podatek dochodowy wyraźnie preferuje przedsiębiorców, a ciężar obciążeń podatkowych w większym stopniu spada na dochody z pracy.

Nie prawdziwą jest powszechna opinia, że podatnik może kształtować swoje sprawy tak, aby wynikające $\mathrm{z}$ nich obciążenia fiskalne były jak najmniejsze. Występujące $\mathrm{w}$ polskim prawie podatkowym rozwiązania pozwalają na niepłacenie podatków przez przedsiębiorców. Polski system podatków dochodowych pozwala przedsiębiorcom omijać obowiązki podatkowe. Ten sposób działania nie dotyczy podatników uzyskujących dochody z innych źródeł, np. wynagrodzenia ze stosunku pracy czy umowy zlecenia.

\section{Literatura}

Ustawa z 29 sierpnia 1997r. Ordynacja podatkowa (tekst jednolity Dz. U. z 2017r. poz. 201 ze zm.) 
Informacja dotycząca rozliczenia podatku dochodowego od osób fizycznych za 2008 rok, Ministerstwo Finansów, Departament Podatków Dochodowych, Warszawa, sierpień 2009r.

Informacja dotycząca rozliczenia podatku dochodowego od osób fizycznych za 2009 rok, Ministerstwo Finansów, Departament Podatków Dochodowych, Warszawa, sierpień 2010r.

Informacja dotycząca rozliczenia podatku dochodowego od osób fizycznych za 2010 rok, Ministerstwo Finansów, Departament Podatków Dochodowych, Warszawa, sierpień 2011 r.

Informacja dotycząca rozliczenia podatku dochodowego od osób fizycznych za 2011 rok, Ministerstwo Finansów, Departament Podatków Dochodowych, Warszawa, sierpień 2012r.

Informacja dotycząca rozliczenia podatku dochodowego od osób fizycznych za 2012 rok, Ministerstwo Finansów, Departament Podatków Dochodowych, Warszawa, wrzesień 2013r.

Informacja dotycząca rozliczenia podatku dochodowego od osób fizycznych za 2013 rok, Ministerstwo Finansów, Departament Podatków Dochodowych, Warszawa, wrzesień 2014r.

Informacja dotycząca rozliczenia podatku dochodowego od osób fizycznych za 2014 rok, Ministerstwo Finansów, Departament Podatków Dochodowych, Warszawa, październik 2015r.

Informacja dotycząca rozliczenia podatku dochodowego od osób fizycznych za 2015 rok, Ministerstwo Finansów, Departament Podatków Dochodowych, Warszawa 2016r.

Informacja dotycząca ryczałtu od przychodów ewidencjonowanych za 2008 rok, Ministerstwo Finansów, Departament Podatków Dochodowych, Warszawa, maj 2009r.

Informacja dotycząca ryczałtu od przychodów ewidencjonowanych za 2009 rok, Ministerstwo Finansów, Departament Podatków Dochodowych, Warszawa, maj 2010r.

Informacja dotycząca ryczałtu od przychodów ewidencjonowanych za 2010 rok, Ministerstwo Finansów, Departament Podatków Dochodowych, Warszawa, maj 2011r.

Informacja dotycząca ryczałtu od przychodów ewidencjonowanych za 2011 rok, Ministerstwo Finansów, Departament Podatków Dochodowych, Warszawa, maj 2012r.

Informacja dotycząca ryczałtu od przychodów ewidencjonowanych za 2012 rok, Ministerstwo Finansów, Departament Podatków Dochodowych, Warszawa, czerwiec 2013r.

Informacja dotycząca ryczałtu od przychodów ewidencjonowanych za 2013 rok, Ministerstwo Finansów, Departament Podatków Dochodowych, Warszawa, lipiec 2014r.

Informacja dotycząca ryczałtu od przychodów ewidencjonowanych za 2014 rok, Ministerstwo Finansów, Departament Podatków Dochodowych, Warszawa, sierpień 2015r.

Informacja dotycząca ryczałtu od przychodów ewidencjonowanych za 2015 rok, Ministerstwo Finansów, Departament Podatków Dochodowych, Warszawa, lipiec 2016r.

Gomułowicz A., Malecka J., 2013, Podatki i prawo podatkowe, Wydawnictwo Prawnicze LexisNexis, Warszawa

Majchrzycka-Guzowska A., 2011, Finanse i prawo finansowe, Wydawnictwo Prawnicze LexisNexis, Warszawa

\section{Abstract}

Taxation has been a complex social, economic, political and legal issue. Taxes have always been and will primarily remain as a tool for the state to gather essential means to perform its functions. Furthermore, taxes have been linked with regulation of economic and social processes, which means, that taxes fulfill following functions: redistributive, stimulus and allocative. Socioeconomic meaning of taxes is reflected in the fact that as a result of imposing taxes the financial and profitable situation of taxpayers changes which influences their decisions: economic, consumption, or about saving etc. Changes in the tax system in 2008-2015 have affected the shape of nominative and effective tax rates. The amount of tax burdens and other fiscal impositions on certain groups of taxpayers caused changes in charging their income. The aim of this article is to evaluate tax burdens in Poland in 2008-2015. Based on this evaluation, an attempt of verifying hypotheses has been made on assumption that tax burdens imposed on individuals involved in nonagricultural activities are lower in comparison with taxation of income from other sources.

Key words: non-agricultural activities, income from other sources, social security contribution, health insurance contribution, tax due 
Informacja o Autorach:

Prof. dr hab. Marian Podstawka

Katedra Finansów

Wydział Nauk Ekonomicznych

Szkoła Główna Gospodarstwa Wiejskiego w Warszawie

ul. Nowoursynowska 166

02-787 Warszawa

e-mail: marian_podstawka@sggw.pl

dr Agnieszka Deresz 